\title{
Determinan Faktor Pengungkapan Modal Intelektual dan Tingkat Pengungkapan Per Industrinya pada Seluruh Perusahaan yang Terdaftar di Bursa Efek Indonesia
}

\author{
Sri Budhi Rezki \\ Universitas Muhammadiyah Yogyakarta \\ sribudhirezki@gmail.com
}

\begin{abstract}
This study aims to examine the influence of corporate governance mechanisms and company characteristics towards the extent of intellectual capital disclosure. The independent variable in this research is proportion of independence board, size of audit committee, profitability, age of company, size of company, and type of industries. The dependent variable in this research is intellectual capital disclosure level. The sample was all companies listed at Indonesia Stock Exchange. The sampling technique used in this study is purposive sampling, which had 146 firms. The analysis of this study uses multiple linear regression. The results of this study indicated that size of audit committee, profitability, size of company, and type of industries had positive and significant influence on extent of intellectual capital disclosure. Eventhough, proportion of independence board and age of company had no significant. Each industry tend to disclose different component of intellectual capital disclosure level to other industries, depend on the characteristics of industries.
\end{abstract}

Keywords: intellectual capital disclosure level, proportion of independence board, size of audit committee, profitability, age of company, size of company, type of industries

\begin{abstract}
ABSTRAK
Penelitian ini bertujuan untuk menguji pengaruh mekanisme tata kelola perusahaan dan karakteristik perusahaan terhadap sejauh mana pengungkapan modal intelektual perusahaan. Variabel independen dalam penelitian ini adalah proporsi dewan independen, ukuran komite audit, profitabilitas, umur perusahaan, ukuran perusahaan, dan jenis industri. Variabel dependen dalam penelitian ini adalah tingkat pengungkapan modal intelektual. Sampel penelitian ini merupakan semua perusahaan yang terdaftar di Bursa Efek Indonesia. Teknik sampling yang digunakan dalam penelitian ini adalah purposive sampling, yang terdiri dari 146 perusahaan. Analisis penelitian ini menggunakan regresi linier berganda. Hasil penelitian ini menunjukkan bahwa ukuran komite audit, profitabilitas, ukuran perusahaan, dan jenis industri memiliki pengaruh positif dan signifikan terhadap tingkat pengungkapan modal intelektual. Meskipun proporsi dewan independensi dan usia perusahaan tidak signifikan. Setiap industri cenderung mengungkapkan komponen pengungkapan modal intelektual yang berbeda dibandingkan industri lainnya, tergantung pada karakteristik industri.
\end{abstract}

Kata Kunci: tingkat pengungkapan modal intelektua, proporsi dewan independen, ukuran komite audit, profitabilitas, usia perusahaan, ukuran perusahaan, jenis industri 


\section{PENDAHULUAN}

Perkembangan teknologi yang begitu pesat membuat dampak besar pada perubahan masyarakat yang menyadari pentingnya pengetahuan dan teknologi. Jika dahulu aset berwujud (tangible asset) seperti investasi dalam bentuk fisik bangunan, mesin dan berbagai macam fasilitas lainnya yang menjadi kunci sumber daya dalam dunia ekonomi dan salah satu faktor vital dalam produksi, kini di perusahaan modern secara berangsur-angsur telah berubah menjadi pengetahuan (knowledge) (Petty dan Guthrie, 2000). Jadi, perkembangan kecanggihan jaringan teknologi dapat merubah cara operasi bisnis dan kompetisi (Yau dkk., 2009).

Sumber daya manusia, ilmu pengetahuan dan teknologi menjadi sumber potensial pada perusahaan modern untuk mendapatkan keunggulan kompetitif yang tidak dapat diperoleh dan ditiru oleh pesaingnya serta mendorong perkembangan dan kesuksesan bisnis di masa depan (Yau dkk., 2009). Oleh karena itu dalam menciptakan nilai, dilakukan dengan pemanfaatan aset-aset individual menjadi sekelompok aset yang sebagian utamanya adalah aktiva tidak berwujud, yaitu modal intelektual (intellectual capital). Adanya modal intelektual akan memberikan peluang perusahaan untuk meningkatkan daya saing melalui penciptaan laba, strategy positioning, inovasi teknologi, loyalitas konsumen, dan peningkatan produktivitas (Istanti, 2009).

Dalam sistem akuntansi, modal intelektual termasuk dalam intangible asset. Namun tidak dapat dicantumkan dalam neraca, karena modal intelektual dianggap sebagai bentuk unaccounted capital. Akibatnya, munculnya kesenjangan informasi karena informasi yang tersedia tidak cukup bagi stakeholders dan juga kurangnya informasi menyebabkan hambatan utama bagi pengakuan pentingnya modal intelektual.

Oleh karena itu, perusahaan di Indonesia dalam meningkatkan relevansi laporan tahunannya akan melakukan Intellectual Capital Disclosure (ICD). Pengungkapan ini dapat dipengaruhi oleh berbagai karakteristik perusahaan (Utomo dan Chariri, 2015). Penelitian yang menguji pengaruh karakteristik perusahaan terhadap ICD telah dilakukan oleh Whiting and Woodcock (2011), Susilowati dkk., (2015), dan Utomo dan Chariri (2015). Selain dipengaruhi oleh karakteristik perusahaan, ICD juga dipengaruhi oleh adanya mekanisme corporate governance (CG). Karakteristik perusahaan yang akan diteliti dalam penelitian ini adalah profitabilitas, ukuran perusahaan, umur perusahaan dan tipe industri. Adapun mekanisme corporate governence yang digunakan adalah proporsi komisaris independen dan ukuran komite audit.

Penelitian ini menarik untuk dilakukan karena beberapa hal, yaitu pertama, belum adanya standar yang menetapkan item-item apa saja yang termasuk dalam aset tak berwujud yang dilaporkan secara mandatory. Kedua, dengan lebih memberdayakan modal intelektual yang diwujudkan dalam aktivitas inovatif, 
diharapkan mampu melakukan diferensiasi produk guna meningkatkan daya saing di tingkat global.

\section{TINJAUAN PUSTAKA DAN PENGEMBANGAN HIPOTESIS Teori Agensi}

Anthony dan Govindarajan (2005) menyatakan satu elemen kunci dari teori keagenan adalah bahwa prinsipal dan agen mempunyai perbedaan preferensi dan tujuan. Hal ini menyebabkan terjadinya agency problem yang disebut dengan asymmetri information yaitu informasi yang tidak seimbang karena adanya distribusi informasi yang tidak sama antara prinsipal dan agen. Menurut Cerbioni dan Parbonetti (2007), corporate governance dan pengungkapan sukarela adalah mekanisme untuk melindungi investor dan membantu mengurangi agency problem. Dengan pengungkapan sukarela, dapat menambah komunikasi ke investor (Healy dan Palepu, 2001) yang membantu investor mengerti tujuan bisnis perusahaan.

\section{Modal Intelektual (Intellectual Capital)}

Menurut OECD (2015), modal intelektual merupakan bagian dari aset tidak berwujud (intangible assets) secara keseluruhan karena ada unsur yang bersifat tidak berwujud (intangible) secara logis bukan merupakan bagian dari modal intelektual, misalnya reputasi, yang merupakan hasil dari penggunaan modal intelektual. Jadi, modal intelektual merupakan pengetahuan yang memberikan informasi tentang nilai tak berwujud perusahaan yang dapat membantu perusahaan untuk menjalankan strateginya dengan efektif dan efisien serta memengaruhi daya tahan dan keunggulan bersaing. Saleh $d k k$. (2010) mengelompokkan modal intelektual ke dalam tiga bagian, yaitu:

\section{Human Capital}

Human capital merupakan lifeblood dalam modal intelektual. Disinilah sumber innovation dan improvement, tetapi merupakan komponen yang sulit untuk diukur. Jadi, human capital dapat diartikan sebagai pengetahuan yang dibawa bersama karyawan ketika mereka meninggalkan organisasi, seperti pengetahuan, kemampuan, sikap dan hubungan.

\section{Internal Structure (Organizational Capital)}

Internal structure merupakan kemampuan organisasi atau perusahaan dalam memenuhi proses rutinitas perusahaan dan strukturnya yang mendukung usaha karyawan untuk menghasilkan kinerja intelektual yang optimal serta kinerja bisnis secara keseluruhan., misalnya sistem operasional perusahaan, proses manufakturing, budaya organisasi, filosofi manajemen dan semua bentuk intellectual property yang dimiliki perusahaan. Seorang individu dapat memiliki tingkat intelektualitas tinggi, tetapi jika organisasi memiliki sistem dan prosedur 
yang buruk maka intellectual capital tidak dapat mencapai kinerja secara optimal dan potensi tidak dapat dimanfaatkan secara maksimal.

3. External Structure (Relational Capital)

External structure merupakan hubungan yang harmonis (association network) yang dimiliki oleh perusahaan dengan para mitranya, baik yang berasal dari para pemasok yang andal dan berkualitas, berasal dari pelanggan yang loyal dan merasa puas akan pelayanan perusahaan yang bersangkutan, berasal dari hubungan perusahaan dengan pemerintah dan masyarakat sekitar. External structure dapat muncul dari berbagai bagian di luar lingkungan perusahaan seperti pelanggan, pemasok, kreditor, jaringan, strategic alliances, dan saluran distribusi

Perubahan lingkungan bisnis yang semakin pesat memberikan banyak pengaruh dalam pelaporan keuangan perusahaan, terutama dalam hal penyajian dan penilaian aset tidak berwujud. Suwarjuwono dan Kadir (2003) menyatakan badan akuntansi internasional juga sedang melakukan pengujian terhadap kerangka kerja pengelolaan dan pelaporan modal intelektual perusahaan. Hasil penelitian ini menunjukkan porsi pengungkapan setiap elemen modal intelektual, dimana 30\% indikator digunakan untuk mengungkapkan human capital, 30\% organizational capital (internal structure) dan $40 \%$ customer capital (external structure).

\section{Proporsi Komisaris Independen}

Komisaris independen bertanggungjawab untuk mendorong diterapkannya prinsip tata kelola perusahaan yang baik di dalam perusahaan. Pemberdayaan dewan komisaris oleh komisaris independen dilakukan supaya dapat melakukan tugas pengawasan terhadap direksi secara efektif dan lebih memberikan nilai tambah bagi perusahaan. Komisaris independen harus mengupayakan agar dewan komisaris melakukan pengawasan dan memberikan nasihat kepada direksi. Dalam rangka memantapkan efektivitas komisaris independen, jumlah komisaris independen dalam satu perusahaan ditetapkan paling sedikit 30\% dari jumlah seluruh komisaris atau paling sedikit satu orang.

Cerbioni dan Parbonetti (2007) menyatakan terdapat pengaruh positif antara proporsi komisaris independen terhadap pengungkapan modal intelektual. Cerbioni dan Parbonetti (2007) meneliti tentang efek corporate governance pada pengungkapan modal intelektual. Berdasarkan uraian tersebut, maka hipotesisnya yaitu :

\section{H1: Proporsi komisaris independen berpengaruh positif terhadap luas pengungkapan modal intelektual.}

\section{Ukuran Komite Audit}

Pengawasan dewan (board monitoring) adalah suatu fungsi yang bukan hanya dari struktur dan komposisi dari dewan komisaris, tetapi juga dari 
subkomite dewan komisaris di mana banyak proses dan keputusan penting dilakukan dan diawasi. Pengawasan ini dilakukan oleh komite yang disebut komite audit. Suatu komite audit terdiri dari mayoritas komisaris independen yang dapat meningkatkan kualitas informasi keuangan untuk memberikan suatu penilaian yang lebih akurat dari keputusan dan kinerja manajemen puncak (Cerbioni dan Parbonetti, 2007). Dewan biasanya mendelegasikan tanggung jawab untuk pengawasan pelaporan keuangan kepada komite audit untuk meningkatkan luas relevansi dan reliabilitas dari laporan tahunan.

Munculnya komite audit dihubungkan dengan pelaporan keuangan yang lebih terpercaya, peningkatan kualitas dan pengungkapan. Berkaitan dengan pentingnya modal intelektual, diharapkan komite audit yang lebih besar akan mempermudah pengendalian internal sehingga dapat menghasilkan peningkatan kualitas pengungkapan modal intelektual yang memiliki nilai bagi perusahaan. Sembiring (2005) dan Abeysekera (2008) membuktikan bahwa ukuran dewan komisaris yang besar akan berdampak pada pengungkapan yang lebih besar. Berdasarkan uraian tersebut, maka hipotesisnya yaitu :

\section{H2: Ukuran komite audit berpengaruh positif terhadap luas pengungkapan modal intelektual.}

\section{Profitabilitas}

Perusahaan yang memiliki kemampuan kinerja keuangan yang baik, akan identik dengan upaya-upaya untuk melakukan pengungkapan yang lebih luas. Luasnya pengungkapan yang dilakukan oleh perusahaan adalah upaya untuk memperoleh dukungan dan mencari simpati para stakeholder-nya. Perusahaan dengan kinerja yang tinggi akan meningkatkan nilai perusahaan dalam proses pembentukan image yang sangat berpengaruh untuk mendapat kepercayaan dari para stakeholder. Oleh karena itu, semakin tinggi kinerja sebuah perusahaan maka semakin banyak pengungkapan modal intelektual ke publik (Li dkk., 2007).

Laba perusahaan didapat dari investasi yang berkelanjutan dalam modal intelektual. Perusahaan yang memiliki investasi lebih banyak dalam modal intelektual akan cenderung mengungkapkan banyak informasi tentang modal intelektual. Oleh karena itu, semakin tinggi laba suatu perusahaan, maka semakin cenderung untuk mengungkapkan informasi tentang modal intelektual. Keputusan untuk mengungkapakan informasi perusahaan akan memengaruhi peningkatan harga saham, sehingga pada penelitian dengan sampel 260 laporan keuangan perusahaan di Spanyol (Garcia-Meca 2007) ditemukan bahwa ada hubungan positif antara pengungkapan modal intelektual dan laba perusahaan. Penelitian ini didukung Chang dkk. (2004), yakni terdapat hubungan positif antara profitabilitas dengan pengungkapan modal intelektual. Berdasarkan latar belakang tersebut, maka hipotesisnya yaitu : 


\section{H3: Profitabilitas berpengaruh positif terhadap luas pengungkapan modal intelektual.}

\section{Umur Perusahaan}

Umur perusahaan menunjukkan perusahaan tetap eksis, mampu bersaing dan memanfaatkan peluang bisnis dalam suatu perekonomian. Alasan yang mendasarinya adalah perusahaan yang berumur lebih tua memiliki pengalaman yang lebih banyak dalam mempublikasikan laporan keuangan. Perusahaan yang memiliki pengalaman lebih banyak akan lebih mengetahui kebutuhan akan informasi perusahaan.

Semakin panjang umur perusahaan akan memberikan pengungkapan informasi keuangan yang lebih luas dibanding perusahaan lain yang umurnya lebih pendek dengan alasan perusahaan tersebut memiliki pengalaman lebih dalam pengungkapan laporan tahunan (White dkk., 2007). Penelitian Istanti (2009) dan Susilowati dkk. (2015) menjelaskan bahwa terdapat hubungan positif antara umur perusahaan dengan pengungkapan modal intelektual. Berdasarkan uraian di atas, maka hipotesisnya yaitu :

\section{H4: Umur perusahaan berpengaruh positif terhadap luas pengungkapan modal intelektual.}

\section{Ukuran Perusahaan}

Purnomosidhi (2006) menyatakan perusahaan yang lebih besar melakukan aktivitas yang lebih banyak dan biasanya memiliki banyak unit usaha dan memiliki potensi penciptaan nilai jangka panjang. Perusahaan besar lebih sering diawasi oleh kelompok stakeholder yang berkepentingan dengan bagaimana manajemen mengelola modal intelektual yang dimiliki, seperti pekerja, pelanggan dan organisasi pekerja. Hal ini didukung oleh White dkk. (2007); Yau dkk. (2009) dan Utomo dan Chariri (2015) menunjukkan adanya hubungan positif signifikan antara ukuran perusahaan dengan pengungkapan modal intelektual. Hasil penelitian yang sama juga terdapat pada penelitian Singh dan Zahn (2008) yang meneliti adanya pengaruh ukuran perusahaan pada pengungkapan modal intelektual di perusahaan gas dan minyak Australia. Berdasarkan uraian tersebut, maka hipotesisnya yaitu :

\section{H5: Ukuran perusahaan berpengaruh positif terhadap luas pengungkapan modal intelektual.}

\section{Tipe Industri}

Informasi modal intelektual secara alamiah bersifat unik terhadap jenis industri tertentu, sehingga luas pengungkapan antara perusahaan dalam industri satu dan yang lainnya berbeda-beda. Hal ini disebabkan oleh risiko dan karakteristik tiap industri berbeda sehingga relevansi item pengungkapan tertentu 
berbeda-beda antar industri. Oleh karena itu, penelitian ini menggunakan kategori dan komponen dari kerangka kerja deskriptif mengenai informasi modal intelektual untuk menganalisa kandungan dari laporan tahunan dengan mengelompokkan antara industri "baru" dan industri "lama". Alasan pengelompokkan ini setelah munculnya perusahaan yang bergerak pada bidang pengetahuan (knowledge), perusahaan tersebut banyak menginvestasikan dalam pengembangan dan penelitian modal intelektual.

Perusahaan yang memiliki pertumbuhan akan pengembangan teknologi tinggi tentunya berpengaruh terhadap perkembangan pengetahuan yang penting bagi karyawan. Bagi perusahaan hal ini penting sebagai bahan inovasi dan pengembangan output serta pengembangan karier karyawan ke depan.

Boedi (2008) menunjukkan terdapat perbedaan pengungkapan modal intelektual yang tergantung pada jenis industrinya. Boedi (2008) menguji perbedaan antara pengungkapan modal intelektual pada jenis industri lama dan industri baru, serta menguji pengaruh pengungkapan modal intelektual terhadap kapitalisasi pasar. Penelitian ini menggunakan sampel 65 laporan tahunan perusahaan dari tahun 2002-2006. Hasil penelitiannya menunjukan bahwa terdapat perbedaan pengungkapan modal intelektual antara jenis industri dan terdapat perbedaan pula pada pengungkapan modal intelektual antara jenis industri lama dan industri baru. Berdasarkan uraian tersebut, maka hipotesisnya yaitu :

\section{H6: Tipe industri berpengaruh positif terhadap luas pengungkapan modal intelektual.}

\section{METODE PENELITIAN}

Obyek penelitian adalah semua perusahaan yang terdaftar di Bursa Efek Indonesia (BEI) tahun 2015. Teknik pengumpulan data dilakukan dengan content analysis dan teknik dokumentasi.

Variabel dependen yang ada pada penelitian ini adalah luas pengungkapan modal intelektual yang diukur dengan menggunakan angka index (ICDIndex).

$$
\text { Score }=\frac{\Sigma d i}{M} \times 100 \%
$$

Score $=$ index pengungkapan modal intelektual (ICDIndex)

di = diberi angka 1 jika suatu informasi diungkapkan dalam laporan tahunan; diberi angka 0 jika tidak diungkapkan.

$\mathrm{M} \quad=$ total jumlah item yang diukur (78 item).

Penelitian ini menggunakan index pengungkapan yang dikembangkan oleh Bukh dkk. (2005) yang berjumlah 78 item dalam 6 kategori yakni karyawan, pelanggan, teknologi informasi, proses, penelitian dan pengembangan serta laporan strategik.

Variabel independen dalam penelitian ini adalah pertama, proporsi 
komisaris independen yang diukur dengan cara menghitung jumlah komisaris independen dibagi jumlah dewan komisaris. Kedua, ukuran komite audit diukur dengan menghitung jumlah anggota komite audit perusahaan. Ketiga, profitabilitas yang bisa diukur dengan ROA (Return On Asset). ROA dihitung dengan laba bersih dibagi total aset tahun tersebut. Keempat, umur perusahaan diukur mulai tahun beroperasinya perusahaan hingga tahun 2015 (LnAge).

Variabel independen kelima adalah ukuran perusahaan diukur dengan jumlah aktiva yang dimiliki perusahaan dalam kurun waktu satu tahun (LnAsset). Keenam, tipe industri menggunakan variabel dummy, yaitu dummy 1 untuk industri baru dan dummy 0 untuk industri lama. Industri baru adalah perusahaan yang bergerak di bidang internet providers, biotechnology, entertainment, internet, IT distribution, high-tech manufacturing, media, retail, software, bank, securities, system integration and telecommunication, dan web service, sedangkan industri lama meliputi food, automobile, chemical, building, electronics, manufacturing, oil, utilities, textiles, tourism, leisure, serta jenis industri sisanya (Bozzolan dkk., 2003).

\section{HASIL PENGUJIAN HIPOTESIS DAN PEMBAHASAN}

Tabel 1 memberikan gambaran statistik deskriptif dari setiap variabel khususnya minimum, maksimum, rata-rata, standar deviasi, dan jumlah pengamatan.

Tabel 1. Statistik Deskriptif

\begin{tabular}{lrrrrr}
\hline & N & Minimum & Maximum & Mean & Std. Deviation \\
\hline ICD & 146 & 0,01 & 0,54 & 0,1736 & 0,09727 \\
INED & 146 & 0,25 & 0,75 & 0,4282 & 0,10939 \\
SAC & 146 & 2 & 6 & 3,32 & 0,759 \\
PROF & 146 & 0,0007 & 19,6783 & 0,218162 & 1,6366840 \\
AGE & 146 & 1,79 & 4,34 & 3,3137 & 0,52198 \\
SIZE & 146 & 21,93 & 33,63 & 28,4106 & 2,13399 \\
IND & 146 & 0 & 1 & 0,26 & 0,440 \\
Valid N (listwise) & 146 & & & & \\
\hline
\end{tabular}

\section{Uji Asumsi Klasik}

Penelitian ini memenuhi seluruh pengujian asumsi klasik. Penelitian ini terbukti memiliki residual berdistribusi normal, tidak terjadi multokolinieritas antar variabel independen dan tidak terdapat adanya heteroskedastisitas. Uji autokorelasi tidak dilakukan dalam peneitian ini karena periode pengamatan hanya satu tahun. 


\section{Uji Hipotesis}

Hasil uji koefisien determinasi $\left(\mathrm{R}^{2}\right)$ yang terlihat pada Tabel 2 menunjukkan koefisien determinasi (Adjusted $\mathrm{R}^{2}$ ) adalah 0,456 atau 45,6\% ini berarti bahwa kemampuan variabel independen secara simultan memiliki pengaruh terhadap variabel luas pengungkapan modal intelektual sebesar 45,6\%.

Tabel 2. Hasil Uji Koefisien Determinasi

\begin{tabular}{llrrrr}
\hline \multicolumn{6}{c}{ Model Summary $^{\mathbf{b}}$} \\
Model & R & R Square & $\begin{array}{c}\text { Adjusted R } \\
\text { Square }\end{array}$ & $\begin{array}{l}\text { Std. Error of } \\
\text { the Estimate }\end{array}$ & $\begin{array}{l}\text { Durbin- } \\
\text { Watson }\end{array}$ \\
\hline 1 & $0,697^{\mathrm{a}}$ & 0,486 & 0,456 & 0,07177 & 1,838 \\
\hline
\end{tabular}

Uji pengaruh simultan menggunakan $\mathrm{F}$ test. Hasilnya pada Tabel 3 menunjukkan semua variabel independen secara simultan memengaruhi variabel luas pengungkapan modal intelektual.

Tabel 3. Hasil Uji Pengaruh Simultan

ANOVA $^{b}$

\begin{tabular}{llrrrrr}
\hline Model & & Sum of Squares & df & Mean Square & F & Sig. \\
\hline 1 & Regression & 0,666 & 8 & 0,083 & 16,170 & $0,000^{\mathrm{a}}$ \\
& Residual & 0,706 & 137 & 0,005 & & \\
& Total & 1,372 & 145 & & & \\
\hline
\end{tabular}

Tabel 4. Hasil Persamaan Regresi Linier Berganda

Coefficients $^{\mathrm{a}}$

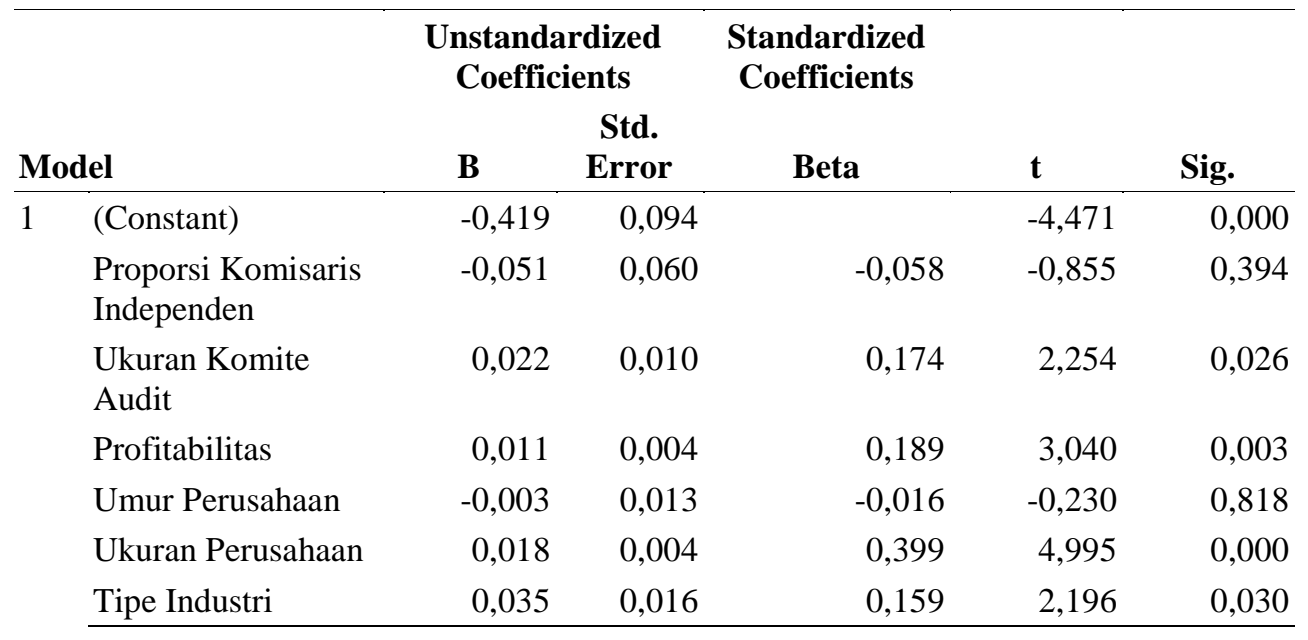

Berdasarkan Tabel 4, variabel proporsi komisaris independen memiliki nilai koefisien regresi sebesar -0,051 dengan signifikansi sebesar 0,394 >0,05 sehingga hipotesis 1 ditolak. Hasil ini bertentangan dengan Cerbioni dan Parbonetti (2007). Mekanisme pemilihan komisaris independen inilah yang masih dapat menciptakan kesempatan penunjukkan anggota komisaris independen yang 
memiliki hubungan kekerabatan atau hubungan baik dengan direksi perusahaan. Hal tersebut akan sangat melemahkan luas pengungkapan modal intelektual dalam aplikasi Corporate Governance, karena dengan adanya transaksi dengan orang dalam (insider transaction), penyelewengan (fraud) dan sebagainya akan membawa perusahaan dalam kondisi yang semakin terpuruk dan hal ini akan membawa imbas pada pengungkapan informasi yang menjadi bagian dalam transparansi informasi.

Berdasarkan Tabel 4, variabel ukuran komite audit memiliki nilai koefisien regresi sebesar 0,022 dengan signifikansi sebesar 0,026 < 0,05 sehingga hipotesis 2 diterima. Begitu pula dengan variabel profitabilitas memiliki nilai koefisien regresi sebesar 0,011 dengan signifikansi sebesar 0,003 $<0,05$ sehingga hipotesis 3 diterima.

Namun, untuk variabel umur perusahaan memiliki nilai koefisien regresi sebesar -0,003 dengan signifikansi sebesar 0,818>0,05 sehingga variabel umur perusahaan tidak terbukti berpengaruh signifikan terhadap variabel luas pengungkapan modal intelektual. Jadi, hipotesis 4 ditolak. Hasil penelitian ini bertentangan dengan hasil penelitian yang dilakukan oleh Istanti (2009) dan Susilowati $d k k$. (2015). Setelah dilakukan analisis, perusahaan yang lebih lama berdiri belum tentu dapat mengungkapkan informasi yang lebih luas dalam laporan tahunannya. Ada kemungkinan perusahaan yang lebih lama berdiri belum tentu berkembang perusahannya atau bahkan cenderung menurun, sehingga hanya sedikit mengungkapkan informasi perusahaannya dalam laporan tahunan.

Untuk hipotesis 5, variabel ukuran perusahaan memiliki nilai koefisien regresi sebesar 0,018 dengan signifikansi sebesar 0,000 $<0,05$ sehingga hipotesis 5 diterima. Selanjutnya, untuk variabel terakhir yakni tipe industri memiliki nilai koefisien regresi sebesar 0,035 dengan signifikansi sebesar 0,030< $\alpha 0,05$ sehingga hipotesis 6 diterima.

Semua jenis industri belum mengungkapkan modal intelektual secara lengkap dalam seluruh kategorinya, yakni kategori karyawan, konsumen, teknologi informasi (TI), proses, penelitian dan pengembangan (R\&D), serta laporan strategis. Hasil penelitian menunjukkan bahwa masing-masing tipe industri lebih condong mengungkapkan modal intelektualnya hanya dalam beberapa kategori saja. Tabel 5 akan menggambarkan tingkat pengungkapan per kategori modal intelektual masing-masing tipe industri dari tinggi ke rendah.

Tabel 5. Ringkasan Tingkat Pengungkapan Modal Intelektual

\begin{tabular}{cllllll}
\hline No & Karyawan & Konsumen & TI & Proses & R\&D & $\begin{array}{l}\text { Laporan } \\
\text { Strategis }\end{array}$ \\
\hline 1 & TKM & TKM & SEC & TAMEG & SEC & TAMEG \\
2 & BNK & SEC & BNK & BNK & KES & BNK \\
3 & SEC & BNK & TKM & PKB & PKB & TKM \\
\hline
\end{tabular}




\begin{tabular}{rllllll}
\hline 4 & GROS & INF & GROS & MED & BNK & SEC \\
5 & TAMEG & KES & TAMEG & KOM & KOM & GROS \\
6 & PAR & TAMEG & RIT & TKM & TAMEG & INF \\
7 & RPB & GROS & ASPK & RIT & TRANS & PAR \\
8 & MED & MED & PKB & TRANS & MAN & MED \\
9 & KES & KOM & TRANS & GROS & ASPK & TRANS \\
10 & KOM & TRANS & KOM & MAN & RPB & RPB \\
11 & ASPK & RPB & PAR & INF & TKM & RIT \\
12 & PKB & MAN & RPB & SEC & GROS & KOM \\
13 & TRANS & RIT & MAN & PAR & INF & MAN \\
14 & RIT & PAR & INF & KES & RIT & KES \\
15 & INF & ASPK & MED & ASPK & PAR & ASPK \\
16 & MAN & PKB & KES & RPB & MED & PKB \\
\hline
\end{tabular}

Keterangan:

Perusahaan Perkebunan (PKB), Perusahaan Pertambangan dan Energi (TAMEG), Perusahaan Manufaktur (MAN), Perusahaan Real Estate, Property, dan Konstruksi Bangunan (RPB), Perusahaan Telekomunikasi (TKM), Perusahaan Pelayanan Jasa dan Transportasi (TRANS), Perusahaan Infrastruktur (INF), Perusahaan Perbankan (BNK), Perusahaan Securities (SEC), Perusahaan Asuransi dan Pembiayaan Keuangan (ASPK), Perusahaan Dagang Grosir (GROS), Perusahaan Ritel (RIT), Perusahaan Jasa Pariwisata (PAR), Perusahaan Media (MED), Perusahaan Pelayanan Jasa Kesehatan (KES), Perusahaan Komputer (KOM)

Berdasarkan Tabel 5, perusahaan telekomunikasi paling tinggi mengungkapkan kekayaan modal intelektualnya dalam kategori karyawan, sedangkan yang paling rendah adalah manufaktur. Alasannya adalah karyawan merupakan tempat bersumbernya pengetahuan yang sangat berguna, keterampilan, dan kompetensi dalam persaingan industri telekomunikasi, dimana berbanding terbalik dengan perusahaan manufaktur yang tidak begitu memanfaatkan karyawan untuk perkembangan industrinya.

Dalam kategori konsumen, paling tinggi pengungkapan modal intelektualnya adalah perusahaan telekomunikasi dan selanjutnya diikuti perusahaan securities, sedangkan yang terendah adalah perusahaan perkebunan. Hal ini mungkin disebabkan, perusahaan telekomunikasi dan perusahaan securities perlu memperhatikan hubungan yang harmonis dengan konsumennya untuk meningkatkan loyalitas para konsumen.

Perusahaan securities, perbankan dan telekomunikasi juga sangat memperhatikan kekayaan modal intelektualnya dalam kategori teknologi informasi, sedangkan penyedia pelayanan jasa kesehatan tidak begitu memperhitungkan pengungkapan modal intelektual pada kategori ini. Alasannya adalah kekayaan modal intelektual pada kategori teknologi informasi merupakan sebuah kekuatan dalam persaingan industri tersebut. 
Perusahaan pertambangan dan energi serta perbankan sangat memperhatikan pengungkapan modal intelektual pada kategori proses, sedangkan yang terendah adalah perusahaan real estate, property, dan konstruksi bangunan. Hal ini dikarenakan proses pemerataan informasi dan pengambilan kebijakan atau keputusan sangat memerlukan analisis yang lebih komplek pada perusahaan yang lebih tinggi mengungkapkan modal intelektual pada kategori proses.

Namun, pengungkapan modal intelektual pada komponen penelitian dan pengembangan (R\&D) lebih banyak diungkapkan pada perusahaan securities dan jasa pelayanan kesehatan, sedangkan lebih sedikit diungkapkan pada perusahaan media. Hal ini mungkin disebabkan penelitian dan pengembangan yang lebih banyak dan mendalam dapat memberikan kekuatan perusahaan untuk bersaing lebih kompetitif.

Kategori laporan strategis lebih banyak diungkapkan pada perusahaan pertambangan dan energi serta perbankan, sedangkan pengungkapan terendah pada perusahaan perkebunan. Hal ini mungkin disebabkan karena pengungkapan modal intelektual yang lebih lengkap dan mendalam tentang perusahaan akan memberikan informasi dan keyakinan perkembangan perusahaan pada pengguna laporan tahunan.

\section{KESIMPULAN, KETERBATASAN DAN SARAN}

Berdasarkan hasil analisis yang telah dilakukan, dapat ditarik kesimpulan bahwa proporsi komisaris independen dan umur perusahaan tidak berpengaruh terhadap luas pengungkapan modal intelektual. Namun, ukuran komite audit, profitabilitas, ukuran perusahaan dan tipe industri berpengaruh positif dan signifikan terhadap luas pengungkapan modal intelektual. Untuk penelitian selanjutnya diharapkan penelitian dilakukan dari tahun ke tahun, sumber data dapat diperluas dengan survai, mempertimbangkan pengggunaan pengelompokan lain misalnya antara industri jasa dan industri non jasa, serta mencari variabel faktor eksternal perusahaan, seperti budaya, kebijakan pemerintah ataupun selera konsumen.

Dalam penelitian ini terdapat keterbatasan bahwa terjadi ketidak seimbangan jumlah perusahaan antara sektor industri lama dan baru. Penelitian ini mungkin membutuhkan penelitian yang lebih mendalam tentang perkembangan tingkat pengungkapan modal intelektual dari tahun ke tahun.

\section{REFERENSI}

Abeysekera, I. 2008. Intellectual Capital Disclosure Trends: Singapore and Sri Lanka. Journal of Intellectual Capital, 9(4): 723-737.

Anthony, R.N. dan Govindarajan, V. 2005. Sistem Pengendalian Manajemen, Edisi 11. Jakarta: Salemba Empat. 
Boedi, S. 2008. Pengungkapan Intellectual Capital dan Kapitalisasi Pasar (Studi Empiris pada Perusahaan Publik di Indonesia. Tesis. Universitas Diponegoro, Semarang.

Bozzolan, S., Favotto, F., dan Ricceri, F. 2003. Italian Annual Intellectual Capital Disclosure. Journal of Intellectual Capital, 4(4): 543-558.

Bukh, P. N., Nielsen, C., Gormsen, P., dan Mouritsen, J. 2005. Disclosure of Information on Intellectual Capital in Danish IPO Prospectuses", Accounting, Auditing \& Accountability Journal, 18(6): 713-732.

Cerbioni, F. dan Parbonetti, A. 2007. Exploring the Effects of Corporate Governance on Intellectual Capital Disclosure: An Analysis of European Biotechnology Companies. European Accounting Review, 16(4): 791-826.

Chang, Y., Chang, H., Chi, H., dan Chiu, W. 2004. Firm Attributes and Intellectual Capital Disclosure: Evidences from IPO Prospectuses in Taiwan. In European Conference on Intellectual Capital, 115-124.

Garcia-Meca, E. dan Martínez, I. 2007. The Use of Intellectual Capital Information in Investment Decision. The International Journal of Accounting, 42(1): 57-81.

Guthrie, J., Petty, R., Yongvanich, K., dan Ricceri, F. 2004. Using Content Analysis as A Research Method to Inquire into Intellectual Capital Reporting. Journal of Intellectual Capital, 5(2): 282-293.

Healy, P. M. dan Palepu, K. G. 2001. Information Asymmetry, Corporate Disclosure, and The Capital Markets: A Review of The Empirical Disclosure Literature, Journal of Accounting and Economics, 31(1-3): 405-440.

Istanti, S.L.W. 2009. Faktor-Faktor yang Mempengaruhi Pengungkapan Sukarela Modal Intelektual". Tesis. Universitas Diponegoro, Semarang.

Li, J., Pike, R., dan Haniffa, R. 2007. Intellectual Capital Disclosurein Knowledge Rich Firms: The Impact of Market and Corporate Governance Factors, Working paperseries.

OECD. 2015. G20/OECD Principles of Corporate Governance, Organisation for Economic Co-operation and Development.

Petty, R., dan Guthrie, J. 2000. Intellectual Capital Literature Review Measurement, Reporting and Management. Journal of Intellectual Capital, 1(2): 155-176. 
Purnomosidhi, B. 2006. Praktik Pengungkapan Modal Intelektual pada Perusahaan Publik di BEJ. Jurnal Riset Akuntansi Indonesia, 9 (1): 1-20.

Saleh, N.M., Hassan, M.S., Jaffar, R., dan Shukor, Z.A. 2010. Intellectual Capital Disclosure Quality: Lessons from Selected Scandinavian Countries. Journal of Knowledge Management, 8 (4): 39-60.

Sembiring, E. R.. 2005. Karakteristik Perusahaan dan Pengungkapan Tanggung Jawab Sosial: Studi Empiris pada Perusahaan yang tercatat di Bursa Efek Jakarta, Simposium Nasional Akuntansi VII.

Singh, I. dan Zahn, J-L.W.M.V. 2008. Determinants of Intellectual Capital Disclosure in Prospectuses of Initial Public Offerings. Accounting and Business Research, 38(5): 409-431.

Susilowati, Y., Wachid, N., Aini, N., dan Anggana, L. 2015. Konsekuensi Ukuran Perusahaan, Profitabilitas, Pengungkitan, Umur Perusahaan, Struktur Kepemilikan, Komisaris Independen terhadap Pengungkapan Modal Intelektual. Management Dynamics Conference.

Utomo, A. I. dan Chariri, A. 2015. Faktor-Faktor yang Mempengaruhi Pengungkapan Modal Intelektual dan Dampaknya terhadap Nilai Perusahaan, Simposium Nasional Akuntansi XVIII.

White G., Lee., A., dan Tower, G. 2007. Drivers of Voluntary Intellectual Capital Disclosure in Listed Biotechnology Companies. Journal of Intellectual Capital, 8(3): 517-537.

Whiting, R. H., dan Woodcock, J. 2011. Firm Characteristics and Intellectual Capital Disclosure by Australian Companies. Jurnal of Human Resourche Costing \& Accounting, 15(2): 102-126.

Williams, S. M.. 2006. "Is Intellectual Capital Performance and Disclosure Practices Related?”, Journal of Intellectual Capital, Vol 2(3), hal 192-203.

Yau, F.S., Chun, L.S., dan Balaraman, R. 2009. Intellectual Capital Reporting and Corporate Characteristic of Public-Listed Companies in Malaysia. Journal of Financial Reporting \& Accounting, 7 (1): 17-35. 